\title{
Three Types of Architectural Educational Strategies (AES) in Sustainable Buildings for Learning Environments in Canada
}

\author{
Jean-Pierre Chupin ${ }^{1, *(\mathbb{D}}$, Morteza Hazbei ${ }^{2}\left(\mathbb{D}\right.$ and Karl-Antoine Pelchat ${ }^{3}$ \\ 1 Faculté de l'aménagement, École d'architecture, Université de Montréal, Montréal, QC H3C 3J7, Canada \\ 2 School of Graduate Studies, Concordia University, Montréal, QC H3G 1M8, Canada; \\ morteza.hazbei@concordia.ca \\ 3 Faculté des Arts et des Sciences, Département de Philosophie, Université de Montréal, \\ Montréal, QC H3C 3J7, Canada; karl-antoine.pelchat@umontreal.ca \\ * Correspondence: jean-pierre.chupin@umontreal.ca
}

check for updates

Citation: Chupin, J.-P.; Hazbei, M.; Pelchat, K.-A. Three Types of Architectural Educational Strategies (AES) in Sustainable Buildings for Learning Environments in Canada. Sustainability 2021, 13, 8166. https:// doi.org/10.3390/su13158166

Academic Editor: Asterios Bakolas

Received: 26 June 2021

Accepted: 18 July 2021

Published: 21 July 2021

Publisher's Note: MDPI stays neutral with regard to jurisdictional claims in published maps and institutional affiliations.

Copyright: (c) 2021 by the authors. Licensee MDPI, Basel, Switzerland. This article is an open access article distributed under the terms and conditions of the Creative Commons Attribution (CC BY) license (https:// creativecommons.org/licenses/by/ $4.0 /)$.

\begin{abstract}
This article explores a trend provisionally called "eco-didacticism" observable for nearly 15 years in art, design and architecture. The corpus concentrates on learning centres as buildings meant to diffuse advanced knowledge in the field of sustainable architecture. We found evidence of additional educational intentions to the pedagogical or scientific programs that these buildings have already been mandated to host and support. A variety of practices or devices have sometimes been added to the architecture, sometimes integrated, while others determine the overall structuring of these educational buildings. Seven cases of "learning centres" built in Canada between 2004 and 2018 have been screened through three epistemological filters distinguishing forms of "architectural didactics": 1-a labeling often quantitative approach, 2-an experiential or practical approach, 3-a visually narrative or iconic approach. While outlining definitions of these Architectural Educational Strategies (AES), we offer initial explanations for their distinctive features. It appears that architects, designers and critics altogether operate on the belief that forms of architectural communication can operate as elements of a language that would be accessible to non-experts. Our conclusion indicates how future research could question the very possibility of giving lessons through formal language and aesthetic features.
\end{abstract}

Keywords: sustainable architecture; sustainable buildings; green architecture; learning centres; educational strategies; educational intentions; eco-didactic architecture; university buildings

\section{Introduction}

This article adheres to the hypothesis of a trend provisionally called "eco-didacticism" whose manifestations have been observable for nearly 15 years in contemporary practices in art, design and architecture [1]. Little work if any has been produced in this new field particularly on cases of environmental architectures. In this varied ensemble of practices gathered under the expression "green architectures", we have delineated a research corpus which pays special attention to learning centres as buildings meant to transmit the most advanced knowledge in the field of sustainable architecture. In order to construct a coherent set for comparative analysis, we focus on a series of awarded "green architectures" assuming that their exemplary character can be attested by awards of excellence. We found evidence of supplementary or complementary educational intentions to the pedagogical or scientific programs that these buildings have already been mandated to host and support. A preliminary inventory carried out by our team over the past 3 years has not only revealed intentions but also a variety of practices or devices that are sometimes added to the architecture, sometimes integrated, while others determine the overall structuring of these learning spaces. Our objective is to contribute to a categorization of these complementary didactic intentions here called "Architectural Educational Strategies" (AES). 


\section{The Questions}

In less than three decades, sustainable architecture has gone from being an isolated endeavor to a disciplinary buzzword and it is now a complex reality. It is no longer possible to define sustainability in architecture and the built environment without specifying their contribution to the objectives of sustainable development as defined by the United Nations [2]. Within the 17 United Nations Sustainable Development Goals for global development to be achieved by 2030, sustainable architecture is most directly associated with the indicators of Goal 11 (Make cities inclusive, safe, resilient and sustainable), of Goal 3 (Good Health and Well-Being) and of Goal 12 (Ensure sustainable consumption and production patterns). Furthermore, sustainable architecture has reached a point where technical answers must be accompanied by carefully crafted explanations. Here, we are not talking of what historians generally call the reception of a work but of a political and democratic imperative in which the capacity of public built environments to fulfill legitimate aspiration for wellness, inclusion and socio-environmental dimensions of sustainability-ever more prominent in the wake of the pandemic — can only be addressed by establishing new dialogs and the possibility of a shared language on environmental quality among all stakeholders. Evaluating the quality of sustainable architecture remains problematic when we consider that the notion of quality itself remains an epistemological gray zone across the design disciplines and professions of the built environment. This is perhaps best exemplified in the scarce mentions of the impacts of the built environment on "Quality of Life and Well-Being" - the only comprehensive encyclopedia on this subject-published in 2014 [3]. While quality has long been defined at the intersection of 3 vectors-also called the Vitruvian triad of solidity, utility and beauty (firmitas, utilitas, venustas), it has been easier to recognize a posteriori, once realized, for example through awards programs, than to formulate as an a priori social demand, particularly considering contemporary crises. The search for a shared understandable definition of environmental quality is now seen as a professional, social, and political imperative aimed at better informing public procurement and professional expertise through a plurality of voices.

The hypothesis of a new educational imperative would potentially explain why, in the field of sustainable architecture, some contemporary architectural interventions cannot be explained solely by the search for better performance, by the achievement of certain objectives or by a simple stylistic theory. In Analyzing Eco-Architecture Beyond Performance [4], Cucuzzella has recently shown that environmental expectations cannot be the result of the mere application of standards or principles. Environmentalism has moved from activism to concrete realization, and its theories and practices have entered a new communicational phase. Let us tentatively call it "eco-didactic" to point out that some architectures manifest additional educational intentions [1]. The questions that we face in this article are therefore of four kinds:

1. In what types of architectural projects can this phenomenon be most tellingly observed?

2. What particular forms do these architectural lessons take?

3. Is it possible to distinguish and categorize these eco-lessons?

4. How can a typology of educational architectural strategies inform or help explain the phenomenon in contemporary practices?

We are not currently in a position to answer the first question satisfactorily, as it would require a large-scale comparison across a wide variety of programs and typologies. In the absence of a convincing analytical grid, it is more prudent to restrict the corpus of study on a coherent typology. This is what we do here by focusing on learning centres and academic programs in the environmental field. Our methodological approach is designed to answer questions 2 and 3 on the inventory and categorization of eco-lessons. We postulate that the particular forms that these additional architectural lessons, intended for a broader audience, can be illustrated and rendered explicit through a comparison of notable cases. In parallel to the inventory of forms, the effort of categorization and naming appears at this stage indispensable. A phenomenon that produces diverse forms can very well generate 
them in a restricted number of identifiable motifs. There is no reason to postulate that chance would be at work in the fields of the built environment. The categorization of "architectural lessons" will nevertheless need to echo those theories that have made a point of rationalizing pedagogy. We will thus have to pass our hypothetical typology through the filter of the main pedagogical theories or even of the major didactic principles since there is no question of confusing these two terms. If pedagogy is a kind of educational metadiscourse, didactics seek to meet teaching objectives by taking concrete actions. What we will call architectural lessons or Architectural Educational Strategies (AES), depending on the case, must be identifiable, readable or observable in concrete terms. Following a fundamental rule of the hermeneutic approach, we let the elements of discourse speak for themselves [5]. Our methodological path calls upon the strengths of comparative analysis and aims at setting up the conditions of future comparative qualitative analysis. (On the main principles of Qualitative Comparative Analysis see: [6-8]. For comparative analysis in architecture see: $[9,10]$.)

The comparisons clearly reveal that the awarded cases of environmental architecture or "learning centres" we have gathered here do not simply tick all the boxes on checklists imposed by standards and certifications. They also want to give "eco-lessons". These buildings actually respond to a double environmental and educational mission. A series of questions can only remain in the background of our research at this stage such as: Who are the target audiences? What specific contents or knowledge or messages constitute the particularities of these "eco-lessons"? Our methodological framework does not seek to verify the didactic efficiency of these environmental lessons on various specialized or non-expert publics. However, the possibility of distinguishing types of architectural lessons rests at the core of the research: In what ways are the messages or lessons conveyed and according to which didactic processes? Is it a question of transforming the whole building into a didactic device? Is it rather a question of adding specific parts whose mission would be properly and not only pedagogical backgrounds as are schools, but educational architectural strategies insofar as they assume a didactic role?

\section{Research Methodology}

To construct the analytical corpus, we have given priority to programs related to research or education because they often address a double audience: on the one hand, the specialized audience specific to education (students, professors, etc.) and, on the other hand, a broader audience since all these projects have a civic or public vocation. However, as we are not trying to demonstrate that certain types of architectural programs are predispose to educational approaches, it is preferable to focus on learning centres whose educational mandate could be coupled with educational strategies that focus on the environmental and ecological characteristics of buildings. To avoid cultural or national distinctions specific to architectural cultures, we have restricted the corpus to a set of seven projects built in Canada between 2004 and 2018. This period corresponds to the generalization of environmental standards but also, as we are studying in another longterm research program, to the rise of awards of excellence in the built environment (for details on the Atlas of Research on Exemplarity in Architecture and the Built Environment see: www.architecture-excellence.org, accessed 20 June 2021). Each of the seven cases studied has received at least one significant award, whether it was an award of excellence more generally or a "green award" specifically recognizing environmental qualities. In fact, all of these cases have received many different awards and can be considered as potentially representative of contemporary excellence in the domain of sustainable architecture.

The overall methodological approach is based on the principles of comparative qualitative analysis, but also on the traditional approaches of discourse analysis as well as of a form of "expert elicitation", which has been recently used to understand and evaluate the SDGs and their links to various sector-driven activities [11-13].

Using a coherent comparable corpus, we analyzed the various "eco-didactic" strategies observable in publications or represented in the discourses coming from designers but 
also from architecture critics as these indicate an intention. Like designers themselves, architectural critics do participate in the constitution of a didactic discourse as evidenced by numerous formulations that convey terms such as model, lessons, messages, etc. The fact that these discourses are often published in professional journals reverberates the eco-lessons and this becomes part of the phenomenon. These empirical indices were sorted and differentiated using 3 main filters. It has been possible to identify these main categories both through a transdisciplinary survey of analogous educational strategies in art, design and architecture. We explain in the next section how these hypothetical categories were confronted to a review of the main theories of education and didactics of science.

The comparison operated through three epistemological filters that we defined as:

- $\quad$ Type 1: Labeling (an attempt to transmit lessons while emphasizing environmental performances, norms or labels)

- Type 2: Experiential (an attempt to transmit lessons while emphasizing a physical and at times haptic approach through the building itself)

- Type 3: Iconic (an attempt to transmit lessons while emphasizing a more visual and at times more symbolic approach)

These three approaches can be found to varying degrees in all the analyzed cases. This indicates that these three "types" of educational strategies should not be understood as mutually exclusive. Since our methodological approach is mainly comparative and since it operates on a limited number of cases, we do not pretend to generalize any of the results. This research is primarily dedicated to the building of an analytical grid that could be used by other scholars for further research in the field of eco-didactic practices in architecture.

\section{Three Contemporary Theories of Education (Behaviorism, Cognitivism, Constructivism)}

Drawing from cultural movements like the Enlightenment and Classical Liberalism, contemporary philosophers such as John Dewey [14-16], Bertrand Russell [17-19] and Noam Chomsky $[20,21]$ have devised new models for education (this list is by no means exhaustive. Other important names such as Maria Montessori and Matthew Lipman could also be mentioned here). Sharing a common humanistic view, these academics claim that the overarching goal of education is to liberate and empower human beings [22]. By promoting cooperation between individuals, Dewey believed that education could strengthen democracy [15]. A staunch proponent of pragmatism, Dewey also thought that education should be grounded in experience and should prepare the pupils for citizenship [23]. In his view, curricula should resonate with civic life and reinforce the idea of community. Through collaboration, students would solve real-world challenges and develop valuable problem-solving skills. While Russell did not abide by Dewey's pragmatism and utilitarian approach, his views on education were very much forward-looking [23]. According to him, education should forge both character and intellect. In doing so, one would ensure that knowledge is used virtuously [17]. Following a similar line of thought, Chomsky added that education could raise moral awareness and improve the rational capacity of agents [24]. As a catalyst for social change, academic institutions should "be a powerful force in shaping and changing community attitudes and values over a period, for militating for or against economic, social and political policies by raising the level of evaluative consciousness" [25]. Incorporating elements of psychology and cognitive science into their works, those eminent philosophers paid close attention to the many developments which occurred outside of the philosophical realm. Of the many research programs that were conducted in psychology during the 20th century, three will be explored here: behaviorism, cognitivism and constructivism.

Stemming from the works of Edward Thorndike [26,27], John B. Watson [28,29] and B.F. Skinner [30,31], behaviorism is a model in learning theory which became widely known during the first half of the 20th century. Emphasizing external factors and environmental conditions, this strategy would be used to reinforce patterns of behavior in subjects [32]. As stated by leading scholars in the field, "the goal of instruction for the behaviorist 
[was] to elicit the desired response from the learner who [was] presented with a target stimulus" [33]. Concerned with "stimulus-response" associations, behaviorists sought not to understand the inner workings and causal mechanisms which underpinned the processes of knowledge acquisition. In their view, the mind was a "black box". It could not be probed and need not be. However, it became increasingly clear that the "inputoutput" formula favored by the behaviorists was inherently flawed, in that it would not fully account for the complexities of human learning. Critics argued that the behavioral approach provided a reductionist picture of psychology and education [32]. In order to address this pressing matter, researchers in cognitive science developed a new model which came to be known as cognitivism.

Gathering increased momentum from the 1950s onwards [34], cognitivism drew from major advances in the fields of linguistics and information theory [35,36]. Focusing on mental processes instead of observable performance, cognitivist theories marked a radical shift from the behavior dominated approach [33]. Taking part in the "cognitive revolution", educators began to modify their own methodology in accordance with those new findings. By promoting cognitive strategies such as concept mapping, synthesizing and analogical learning, educators meant to facilitate the process of knowledge acquisition and organization [33]. By encouraging students to integrate academic material and connect notions in meaningful ways, one would ensure that the information transmitted by the teacher would be properly retained. Concerned with the reception, storage and retrieval of propositional content [33], the cognitive approach aims at the formation of well-structured and enduring memories in the minds of learners through methods of optimization.

Emerging in the 1970's and 1980's, constructivism challenged the behaviorist and cognitivist assumption that knowledge is independent from the mind. Buttressed on the pioneering works of Jean Piaget [37,38] and Jerome Bruner [39,40], "[c]onstructivism is a theory that equates learning with creating meaning from experience" [33]. Proponents of this doctrine claim that knowledge is created rather than acquired. Stressing the relation between the subject and his environment, constructivists assert that learning is an interactive process which is determined by contextual variables [33]. Consisting of personal and flexible interpretations, knowledge is co-produced by the agent and the situation. Instead of being a passive listener, the learner is actively involved in the construction of meaning through problem-solving scenarios. Reflecting upon past experiences, he is able to manipulate information [33] and to dynamically adjust his understanding of the world. Being intrinsically motivated [32], the learner also seeks to broaden his perspectives and to multiply encounters. Free to explore as he so wishes, the subject draws from a wide gamut of experiences to make sense of his own reality. Aptly described as a sense maker, the learner is on a journey of discovery, both personal and interpersonal [32]. Underlined by social constructivists, the collaborative aspect of learning soon became an integral part of instructional design [41,42]. Similarly, the increased focus on meaningful experiences led to the development of experiential learning [43].

In our methodological framework, we postulate that labeling and iconic AES are more akin to cognitivism, while the experiential AES has more in common with constructivism. Having looked at three types of Architectural Educational Strategies from the standpoint of instructional design, we will now summarize the results of a comparison of AES in seven cases of environmental learning centres in Canada.

\section{Comparative Analysis}

Our comparisons operated on two levels. On the one hand, we compared seven cases of learning centres built from 2004 to 2018 and, on the other hand, we compared a smaller reference group of "non-academic" awarded green architectures mainly: a library built in 2004 and two office complexes built in 2015 and 2016 (Table 1). We ranked the projects according to three grades. Grade 2 shows there is a high emphasis on the lesson. Grade 1 shows the project somewhat focused on the lesson and Grade 0 shows that no sign of the lesson can be found in the project (Table 2). Figure 1 already shows a clear difference in 
educational strategies. The nonacademic cases that we studied in parallel with learning centres (one library, one shopping mall and one office building) all have received similar awards for their overall qualities or specifically for their environmental performances. However, we noticed that they entered in the category we call "labeling", for example in simply adding "Leed platinum" on the entrance of the building. This did not inform our study of Architectural Educational Strategies and did not challenge the analytical grid in a fruitful way. This is why, at this stage, we decided to focus on learning centres as they seem to articulate the three strategies in a more informative manner (see Figure 1).

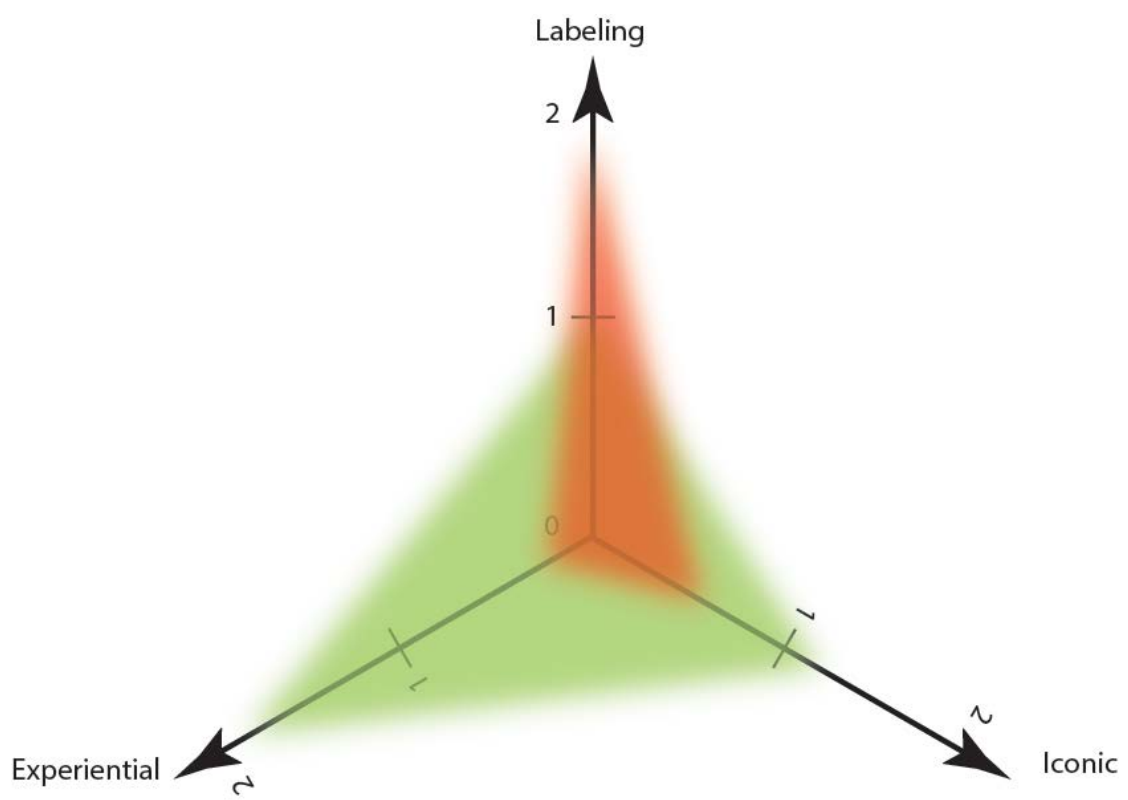

Figure 1. Eco-lessons of academic (in green) and less academic (in red) sustainable buildings.

Table 1. Academic and less academic cases.

\begin{tabular}{ccccc}
\hline \multicolumn{1}{c}{ Project Name } & Year & Labeling & Iconic & Experiential \\
\hline $\begin{array}{c}\text { Joyce Centre for Partnership \& } \\
\text { Innovation (JCPI) }\end{array}$ & 2018 & 1 & 2 & 2 \\
\hline $\begin{array}{c}\text { Wood Innovation and Design Centre } \\
\text { University of Calgary-Energy }\end{array}$ & 2014 & 1 & 2 & 2 \\
\hline $\begin{array}{c}\text { Environment Experiential Learning } \\
\text { Centre }\end{array}$ & 2011 & 1 & 2 & 2 \\
\hline $\begin{array}{c}\text { Centre for Interactive Research on } \\
\text { Sustainability (CIRS) The University of } \\
\text { British Columbia }\end{array}$ & 2011 & 1 & 1 & 2 \\
\hline $\begin{array}{c}\text { Humber Arboretum Centre for Urban } \\
\text { Ecology }\end{array}$ & 2007 & 1 & 1 & 2 \\
\hline $\begin{array}{c}\text { Integrated Learning Centre-Beamish } \\
\text { Munro Hall }\end{array}$ & 2004 & 2 & 2 & 2 \\
\hline $\begin{array}{c}\text { University of Guelph-Humber } \\
\text { comparison }\end{array}$ & 2004 & 2 & 2 & 2 \\
\hline \begin{tabular}{c} 
Humple exemplars \\
\hline
\end{tabular} & 9 & 11 & 14 \\
\hline
\end{tabular}


Table 1. Cont.

\begin{tabular}{ccccc}
\hline Project Name & Year & Labeling & Iconic & Experiential \\
\hline & Less academic sustainable exemplars & & \\
\hline Queen Richmond Centre West & 2016 & 2 & 1 & 0 \\
\hline TELUS Garden & 2015 & 2 & 1 & 1 \\
\hline Bibliothèque Raymond-Lévesque & 2004 & 2 & 0 & 0 \\
\hline comparison & & 6 & 2 & 1 \\
\hline
\end{tabular}

Grey background: divides two main parts of the table.

Table 2. How cases are scored by eco-lessons.

\begin{tabular}{|c|c|c|c|}
\hline & 0 & 1 & 2 \\
\hline Labeling & $\begin{array}{c}\text { No emphasis on } \\
\text { quantitative attributes } \\
\text { of sustainable } \\
\text { architecture }\end{array}$ & $\begin{array}{c}\text { Somewhat focused on } \\
\text { quantitative attributes } \\
\text { of sustainable } \\
\text { architecture }\end{array}$ & $\begin{array}{l}\text { High emphasis on some } \\
\text { typical quantitative } \\
\text { attributes of sustainable } \\
\text { architecture }\end{array}$ \\
\hline Iconic & $\begin{array}{c}\text { No sign of } \\
\text { communicational } \\
\text { devices or symbolic } \\
\text { discourse }\end{array}$ & $\begin{array}{l}\text { Somewhat focused on } \\
\text { communicational } \\
\text { devices or } \\
\text { symbolic discourse }\end{array}$ & $\begin{array}{l}\text { Highly focused on } \\
\text { symbolic and } \\
\text { communicational } \\
\text { devices }\end{array}$ \\
\hline Experiential & $\begin{array}{l}\text { Building by itself does } \\
\text { not convey } \\
\text { any eco-lessons }\end{array}$ & $\begin{array}{c}\text { Building partly } \\
\text { conveys eco-lessons }\end{array}$ & $\begin{array}{l}\text { Highly focused on } \\
\text { building as a learning } \\
\text { experience }\end{array}$ \\
\hline
\end{tabular}

\section{Academic Sustainable Cases Analyses}

\subsection{The Joyce Centre for Partnership \& Innovation (JCPI)}

Designed by B + H Architects and opened its doors to students in the fall of 2018, the Joyce Centre for Partnership \& Innovation (JCPI) at Mohawk College's Fennel Campus in Hamilton, Ontario, is one of the region's first and largest net-zero institutional buildings. The 96,000 square-foot facility is a catalyst for change in the region, positioning Mohawk College as a knowledge centre for carbon-neutral technologies and operations [44]. The building received the Awards of Excellence in Innovation in architecture in 2019 from the Royal Architectural Institute of Canada (RAIC) [45]. It also received Zero Carbon Building (ZCB) Standard certification in both the Design and Performance categories as a first building from the Canada Green Building Council (CaGBC) [46].

The Centre became one of 16 projects in 2017 from across Canada to be chosen as a pilot project for CaGBC's new Zero Carbon Building Standard [47]. The Centre features solarpowered, state-of-the-art labs, workshops, open study spaces and flexible lecture theaters (Figure 2). The mechanical and electrical spaces, as well as the green roofs, are accessible to all and intended to be part of the learning environment [44]. The design prioritizes the end users, Mohawk's students and staff, creating a social learning environment that will become a driver of innovation [48]. 


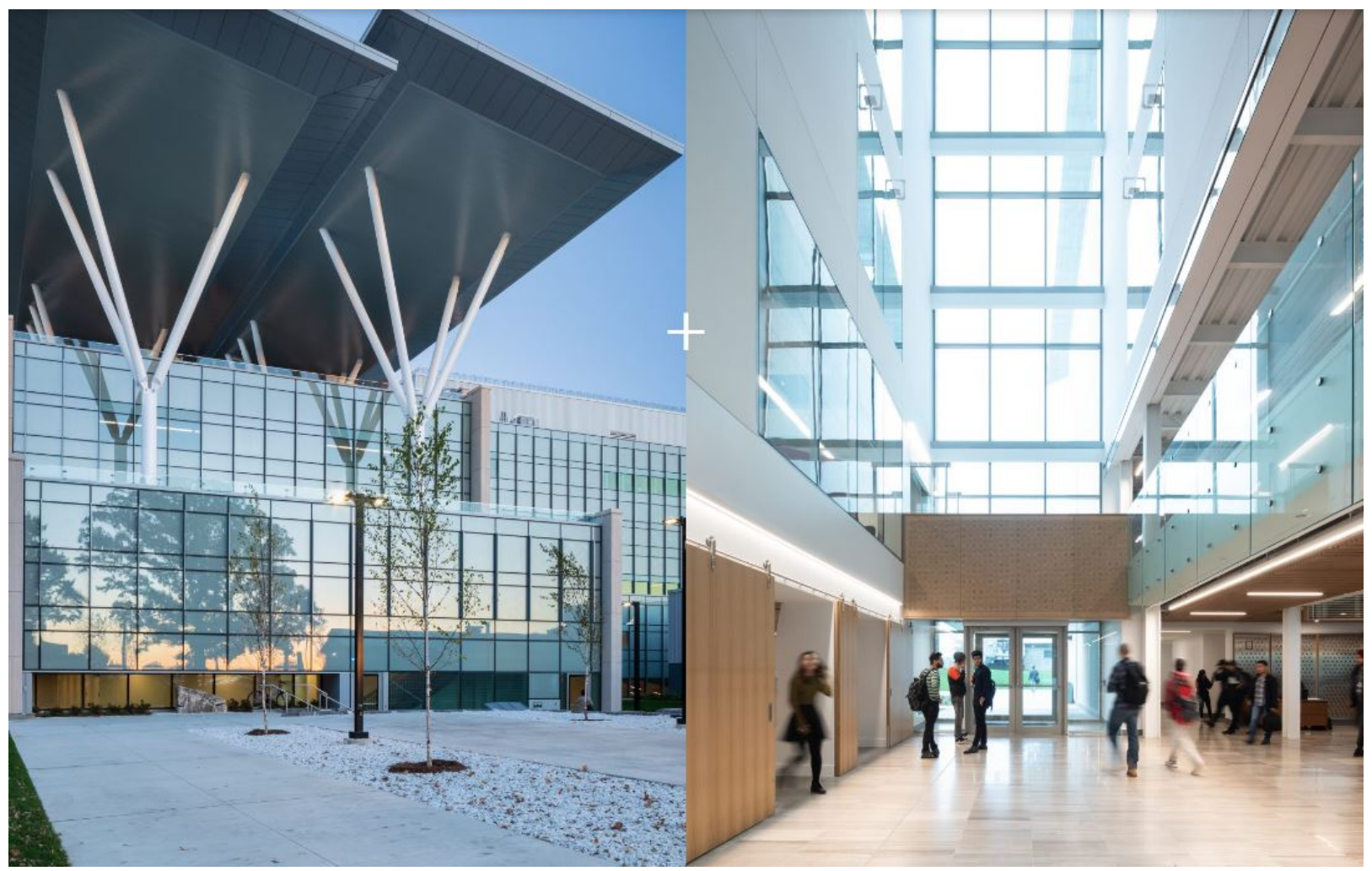

Figure 2. Joyce Centre for Partnership \& Innovation (JCPI). Source: https://bharchitects.com/en/project/mohawk-collegejoyce-centre-for-partnership-innovation/ (accessed on 3 June 2021).

Our discourse analysis of performances and architectural characteristics confirm a high emphasis on experiential and iconic educational strategies and a moderate recourse to labeling attributes. Notably, this was considered a pilot project for CaGBC's new Zero Carbon Building Standard (Figure 3).

\section{- $\quad$ Labeling $=$ Moderate}

As the reviewers explain [46], the centre was constructed with an innovative highperformance building envelope that minimizes heating and cooling demand, an all-electric geo-exchange system and a rooftop photovoltaic system. These systems performed with better-than-expected results, contributing to the performance certification, which is verified annually. Moreover, the college is playing a key role in advancing the zero-carbon building industry through its active support of the ZCB Standard, particularly as one of only three education institutions across Canada to be named as a pilot project for the Standard [49].

- $\quad$ Iconic $=$ High

The building is under a photovoltaic (PV) system "iconic roof" which provides enough carbon-free energy to power the building [49]. These PV panels in building roofs are a bold showcase of eco-design.

- $\quad$ Experiential $=$ High

As Mohawk College Chief Building and Facilities Officer, Tony Cupido explains: “We believe employers will be looking to significantly boost their understanding of carbonneutral technologies and operations due to provincial mandates. The Joyce Centre will allow us to become a knowledge centre for this emerging point of emphasis. We aren't just building a centre to house new lab space, in many ways we're building the lab itself" [44]. This is a living lab for students, offering them hands-on access to the monitoring and operations of a ZCB-certified building [46]. "It will give students the chance to understand the equipment and the different parts and elements to the building," said 
McKerlie [50]. Tony Cupido, Research Chair, Sustainability at Mohawk College adds that the centre provides a unique zero carbon facility for students, faculty and staff and creates an atmosphere of exceptional interdisciplinary collaboration in teaching, research and wellbeing leading by example [46]. These teaching and learning examples consist of exposed structural connections and mechanical and electrical systems in public areas, such as access to green roof terraces, and graphic user interfaces showcasing building systems [49].

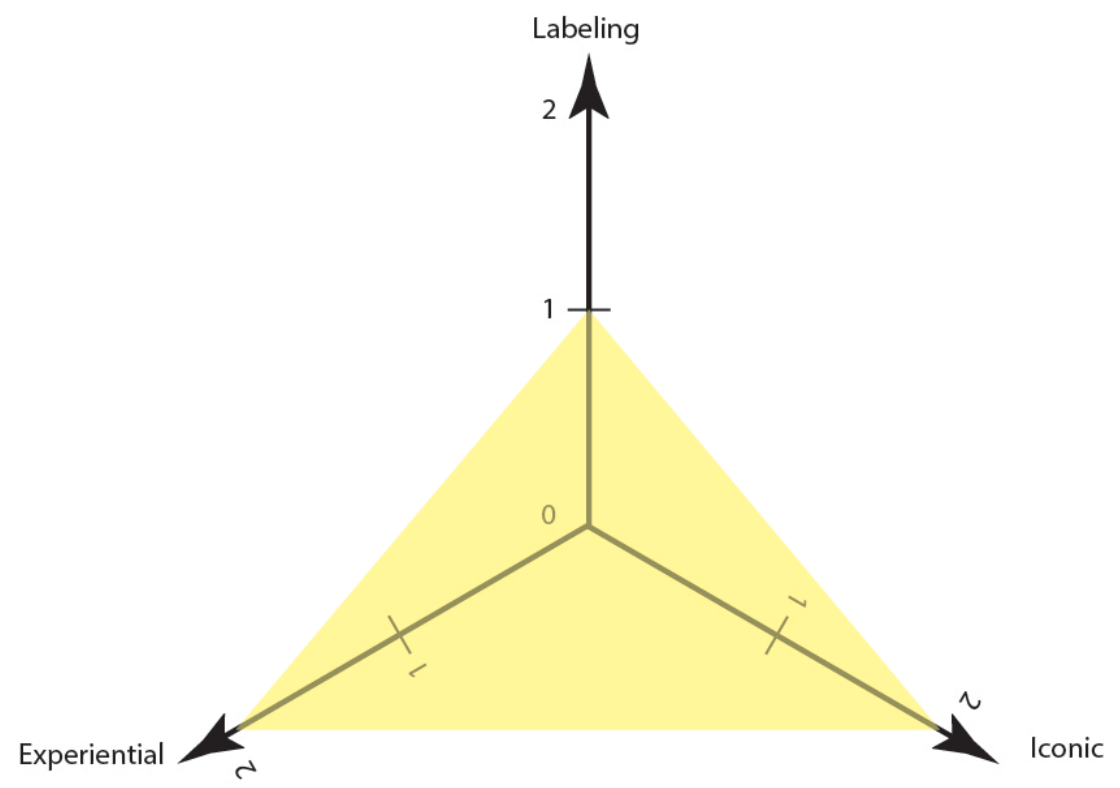

Figure 3. Importance levels of eco-lessons in Joyce Centre for Partnership \& Innovation (JCPI).

\subsection{Wood Innovation and Design Centre}

Designed by Michael Green Architecture (MGA), the Wood Innovation and Design Centre was built in 2014. Located in the city of Prince George in British Columbia, it serves both academic and administrative purposes. The building received the Governor General's Medals in Architecture in 2015, which is considered one of the most prestigious awards in Canada as it is managed by both the Royal Architectural Institute of Canada (RAIC) and the Canada Council for the Arts. The project received several other prestigious national awards for innovation from national and provincial institutions [51].

As presented by journalist Emily Hooper in Architect, the journal of the American Institute of Architects, "Michael Green Architecture has designed the world's tallest, modern timber structure (in 2014), and a showcase for the modern timber building" in terms of engineered timber material, construction, structural and architectural innovations [52] (Figure 4).

Our analysis of discourses, performances and architectural attributes shows a high level of experiential and iconic educational strategies and a moderate recourse to labeling attributes. However, the building is obviously a showroom of performances (Figure 5). 


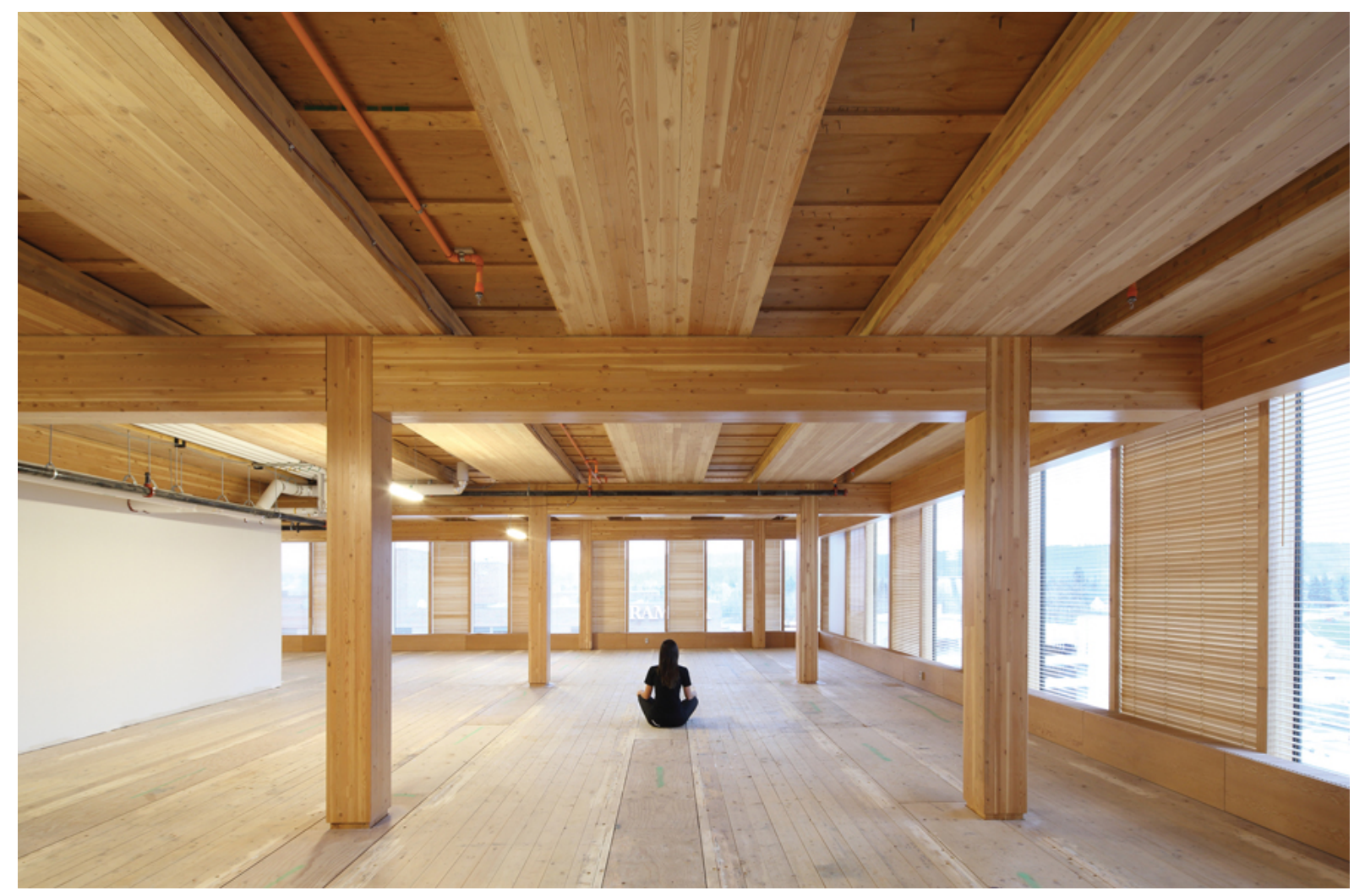

Figure 4. Wood Innovation and Design Centre by Michael Green Architecture. Photo: Ema Peter, 2015.

\section{- $\quad$ Labeling $=$ Moderate}

The architect further explains: "The WIDC project is a global milestone for mass timber construction. The BC government has demonstrated exceptional leadership in the advancement of ideas that will reshape our cities with healthier, more energy-efficient and more climate-sensitive building solutions. The advancement of mass timber and tall wood buildings requires the evolution of our building codes around the world" [53].

\section{- $\quad$ Iconic $=$ High}

The building has become a literal icon of the new possibilities of timber construction and its image has been wildly disseminated. It aims to communicate that mass timber structures can be economic, safe and environmentally superior to other building materials [54].

\section{- $\quad$ Experiential $=$ High}

Unsurprisingly, as a showcase of wood construction, the building has been designed to be experienced. It teaches the possibilities as well as performances advantages offered by timber structures. The first three stories of the WIDC are occupied by the University of Northern British Columbia, where the first Master of Engineering in Integrated Wood Design Program was developed. Guido Wimmers, a professor in the previously mentioned program, elaborates: "It is bragging a little bit in terms of showing off the material. Everything is transparent and you can actually see how it was built" [55]. The building and its connection details also aim to act as experiential models for students, designers, and engineers. As a model, WIDC is a communication device to demonstrate that the timber construction technology can be efficient and easily repeatable in different projects [53]. It aims to encourage institutions and organizations to take up this type of construction. For Shirley Bond, Minister of Jobs, Tourism and Skills Training, and MLA for Prince George, "it [the building] stands as an example of the possibilities" [56]. For architecture critic 
Trevor Boddy: "Being a demonstration project means that many design details exist to show possibilities-there is a strong rhetorical dimension to this tower" [57], but for Boddy, the building is not only a showroom, it should also be seen as an apostolic device to be experienced physically and not only online: "WIDC should become a pilgrimage point for every Canadian architect interested in the new possibilities of wood. When it comes to a true appreciation of the substance of architecture, one site visit is worth 1,044,911 page views" [57].

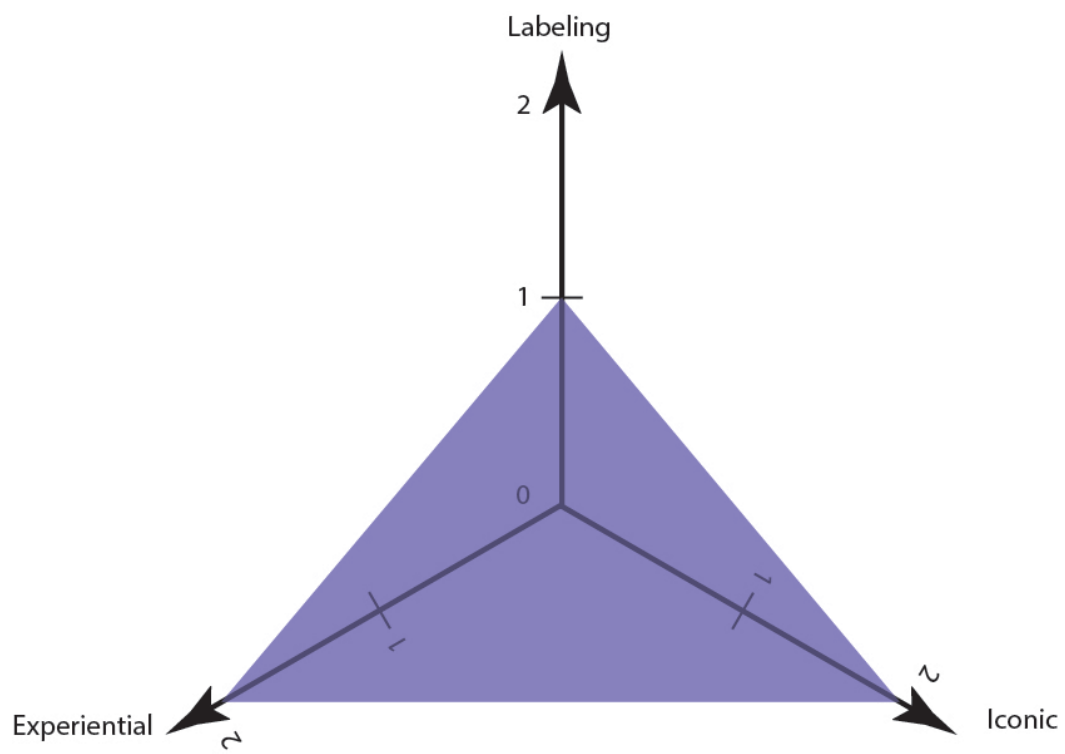

Figure 5. Importance levels of eco-lessons in Wood Innovation and Design Centre.

\subsection{University of Calgary -Energy Environment Experiential Learning Centre}

The University of Calgary-Energy Environment Experiential Learning Centre was opened in September 2011 in Calgary, AB and designed by Dialog Alberta, Perkins\&Will Canada. The 26,200 square meters, five-floor facility provides instructional space, laboratories and space for faculty and staff [58]. In 2013, the building received the Special Jury Award-Animating the Program from AIBC Architectural Awards organization [59] and LEED Platinum certification in April 2013 [60].

Among its notable sustainability features are geothermal earth tubes that precondition the air, triple-glazed windows and natural ventilation. Despite its size, daylight penetrates most building areas through generous interior glazing and large perimeter openings, reducing the need for artificial lighting. In addition, the exterior aluminum paneling is angled down on the south façade to direct sunlight into a pedestrian square. In contrast, the panels on the north street-side façade are oriented upwards, bouncing light into the sky and making the building appear brighter [60] (Figure 6). 


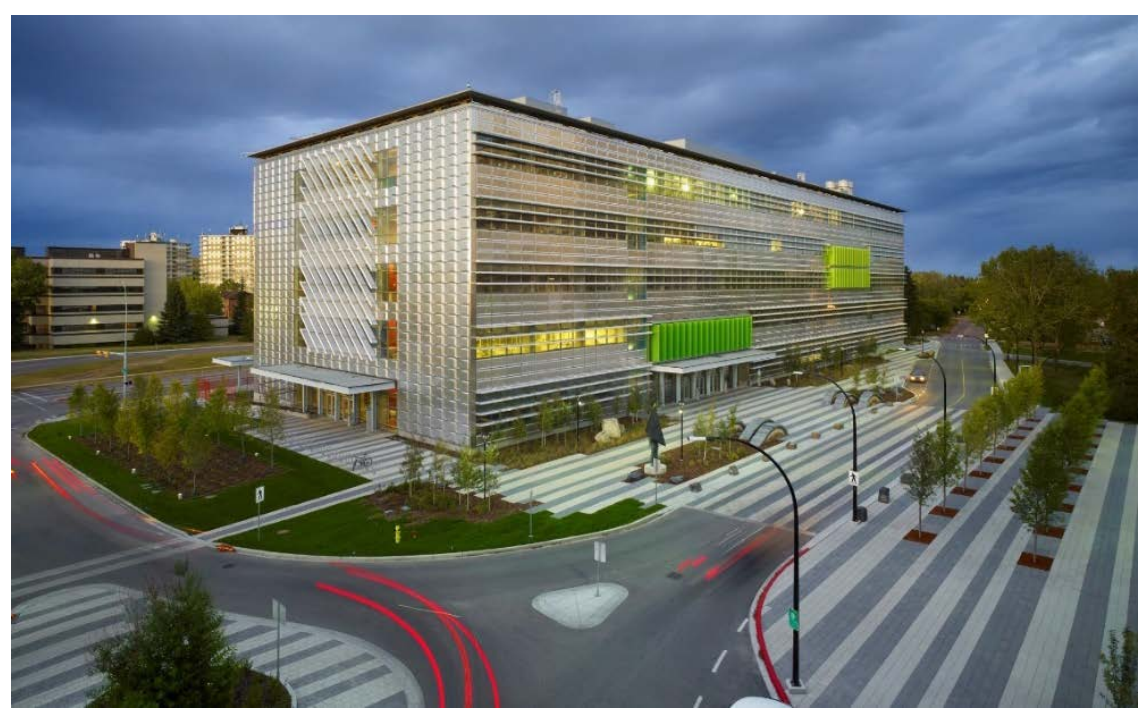

Figure 6. Energy Environment Experiential Learning Centre (EELC), University of Calgary. Source: https:/ / www.archdaily.com/356805/energy-environment-experiential-learning-Perkins\& Will (accessed on 5 July 2021). Reproduced with permission from Tom Arban Photography Inc.

Regarding its eco-didactic lessons, our analysis reveals that the labeling lessons are at a moderate level. However, there is a high emphasis on iconic and experiential lessons (Figure 7).

\section{- $\quad$ Labeling $=$ Moderate}

The building is one of the most energy-efficient laboratory buildings in North America, using 78\% less energy than conventional buildings of the same type. Features include automatic lighting, solar collectors and solar shutters, cooling towers and rainwater capture mixed with recycled process water for plumbing [61].

- $\quad$ Iconic $=$ High

Bright green automated louvers on the building's south façade are the sign of a green building. Additionally, they symbolically convey green design and an eco-friendly message to the community. The building is a recognizable landmark for cabbies and students [61].

"Oh, you mean the shiny one."

-Taxi driver to Peter Busby, en route from Calgary airport to EEEL. [60]

- $\quad$ Experiential $=$ High

The building is designed to be student-centric and provides hands-on and experiential learning opportunities for students [58]. Engineering students can observe the automated green louvers on the south façade pivot in response to the movement of the sun. Junior geoscientists can examine a series of arches by the south entrance that is both decorative and didactic: the forms comprise natural stone layered in correct geological order, demonstrating the standard entrapment of oil and gas in sub-surfaces. Inside, plumbing to control in-slab radiant heating and cooling systems are revealed behind glass access doors [60]. Mechanical systems at the ceiling level are exposed and meticulously labeled. The visual effect of these narrow pipes in perfect parallel alignment running the length of hallways and around corners is one of a kinetic sculpture in stationary mode, or, if you turned the lights off, they reminiscent perhaps the set of Tron [60]. EEEL's theme of "science on display" means teaching spaces are available for view through generous internal and external glazing. The building's structural, mechanical and electrical systems are all exposed for teaching and demonstration opportunities [58]. Design architect Peter Busby of Perkins\&Will Canada explains, "we wanted EEEL to be intelligible, to demonstrate a high degree of environmental performance. There is no mystery-you can see how the building responds to environmental stimulus" [60]. 


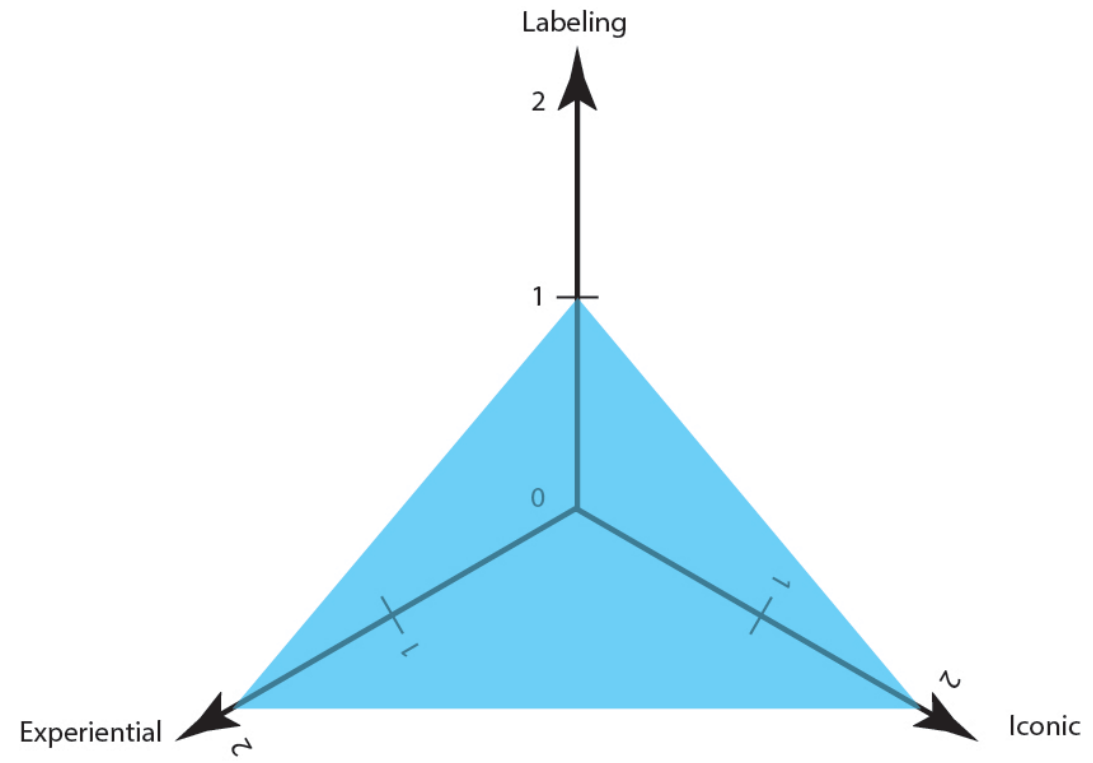

Figure 7. Importance levels of eco-lessons in the University of Calgary.

\subsection{Centre for Interactive Research on Sustainability (CIRS)}

Designed by Peter Busby, the construction was completed by Perkins\&Will in 2011. Located on a dense site at the University of British Columbia (UBC) in Vancouver the 5675 $\mathrm{cm}^{2}$ "living lab" is designed into two four-floor wings, linked by an atrium that serves as a building lobby, with an entry to a daylit 450-seat auditorium and a "social condenser" space [62]. CIRS was first conceived in 1999 by Dr. John Robinson, a professor at UBC, to create a sustainability showcase in the province of British Columbia. A building to push the envelope of sustainable design by integrating passive design strategies with the most advanced sustainable technologies of the time to achieve a high-performance building [63] (Figure 8). The building received the RAIC Awards of Excellence in 2015 from the Royal Architectural Institute of Canada (RAIC) and Canada Green Building Council [64].
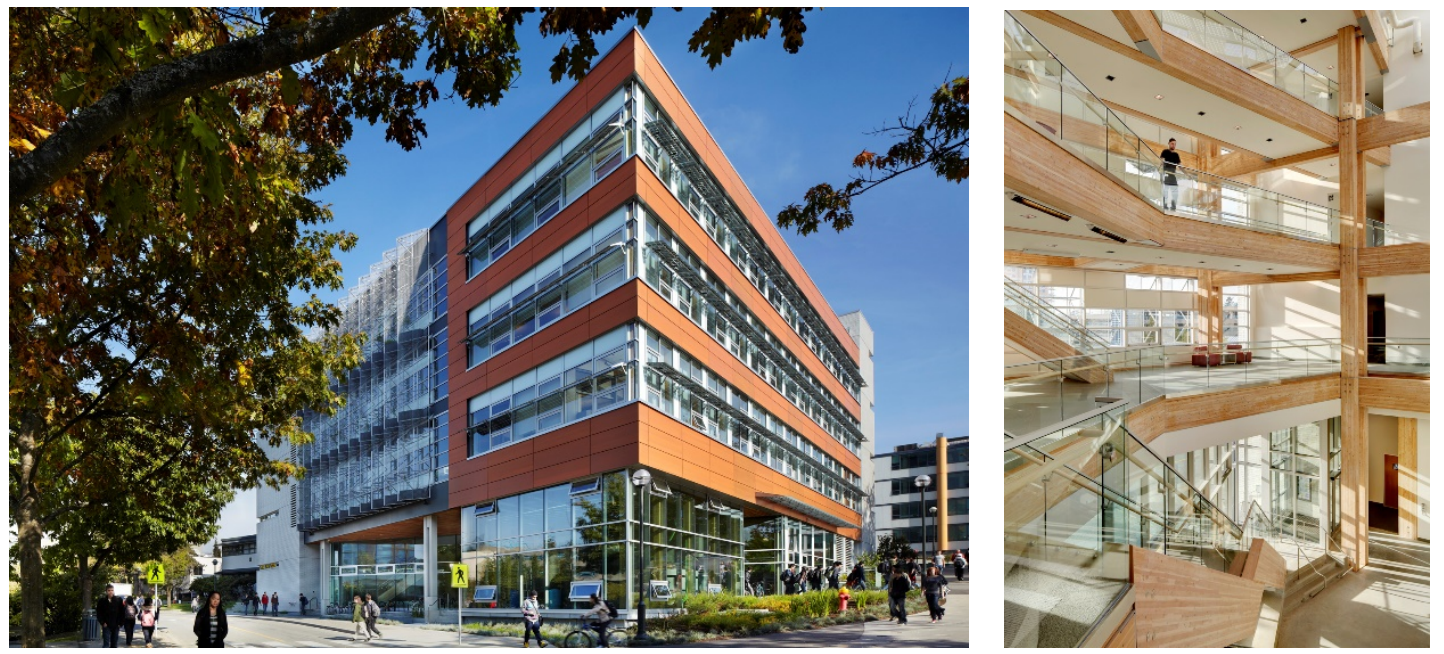

Figure 8. Centre for Interactive Research on Sustainability (CIRS) The University of British Columbia. Photo: Martin Tessler/Courtesy: Perkins\&Will.

Our assessment shows that the building highly focuses on experiential eco-lessons and moderate labeling and iconic lessons (Figure 9).

- $\quad$ Labeling $=$ Moderate 
Targeting LEED Platinum status, CIRS was planned to be "net positive" in seven ways-energy, structural carbon, operational carbon, water, turning passive occupants into active inhabitants, promoting health and productivity and contributing happiness. This "living building" harvests sunlight, captures waste heat from a nearby building, exchanges heating and cooling with the ground, and returns 600-megawatt-hours of surplus energy back to the campus while removing 170 tons of GHG emissions annually. Designed to supply $100 \%$ of the facility's water needs, CIRS collects rainwater for potable use and purifies wastewater on-site through solar aquatic biofiltration. CIRS's wood structure stores 904 tons of carbon, reducing the carbon footprint compared to the average UBC building by almost $90 \%$ [62]. Additionally, to increase its resiliency to change and reduce its total cost of ownership, strategies such as mechanical connections to join structural components were applied, enabling the complete disassembly and repurposing of the building's constituent components [63].

- $\quad$ Iconic $=$ Moderate

The Centre for Interactive Research on Sustainability (CIRS) was designed to be the most sustainable building in North America [62]. More than a building, CIRS is a research tool that demonstrates the possibilities in sustainable design and construction, catalyzing change [62].

- $\quad$ Experiential $=$ High

By displaying environmental performance in real-time, the building's advanced interaction technologies draw attention to the notions of sustainability and climate change [62]. CIRS maximizes passive environmental strategies and demand reduction and puts sustainable systems on display [62]. Moreover, the atrium is an educational space where all of these strategies are visible [62].

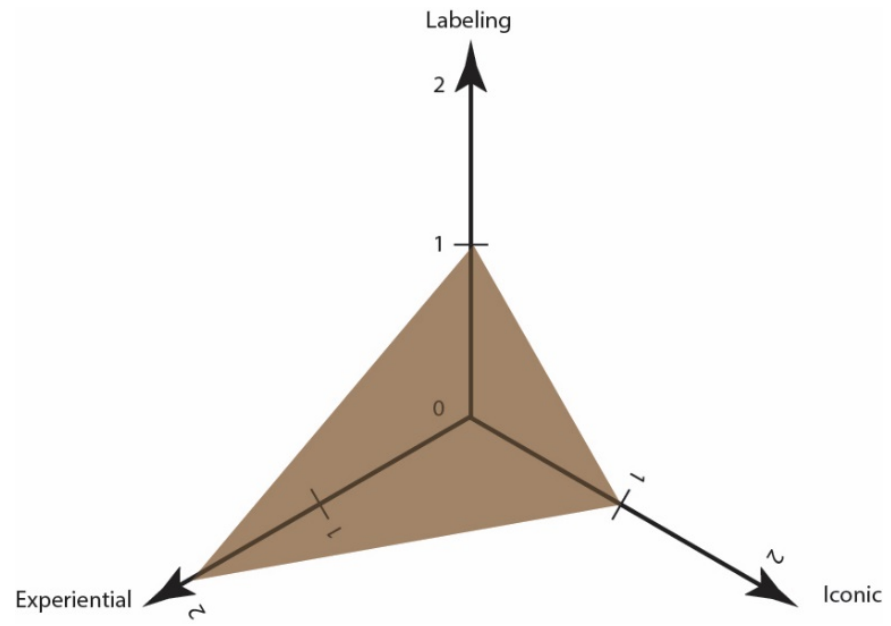

Figure 9. Importance levels of eco-lessons in the Centre for Interactive Research on Sustainability (CIRS).

\subsection{Humber Arboretum Centre For Urban Ecology}

Located behind Humber College's North Campus, this striking two-story glass building is home to the Humber Arboretum's educational programs and special events. It consists of 250 acres of land comprising botanical gardens, natural areas surrounding the Humber River, trails, wetlands, ponds and ravines [65]. The Centre for Urban Ecology is jointly owned by the City of Toronto, the Toronto and Region Conservation Authority and Humber College. Designed by Prime Consultant THA in collaboration with architects Alliance, opened in 2007, it is one of the first buildings in Toronto to receive a LEED Gold certification and it has won numerous awards for design excellence [66]. The Centre for Urban Ecology provides educational opportunities in horticulture and environmental 
stewardship, while promoting the advancement of technology in the service of preserving the natural world [67]. The building also provides a first-rate venue for education and research on urban ecology and an up-to-date example of environmental sustainability [68] (Figure 10).

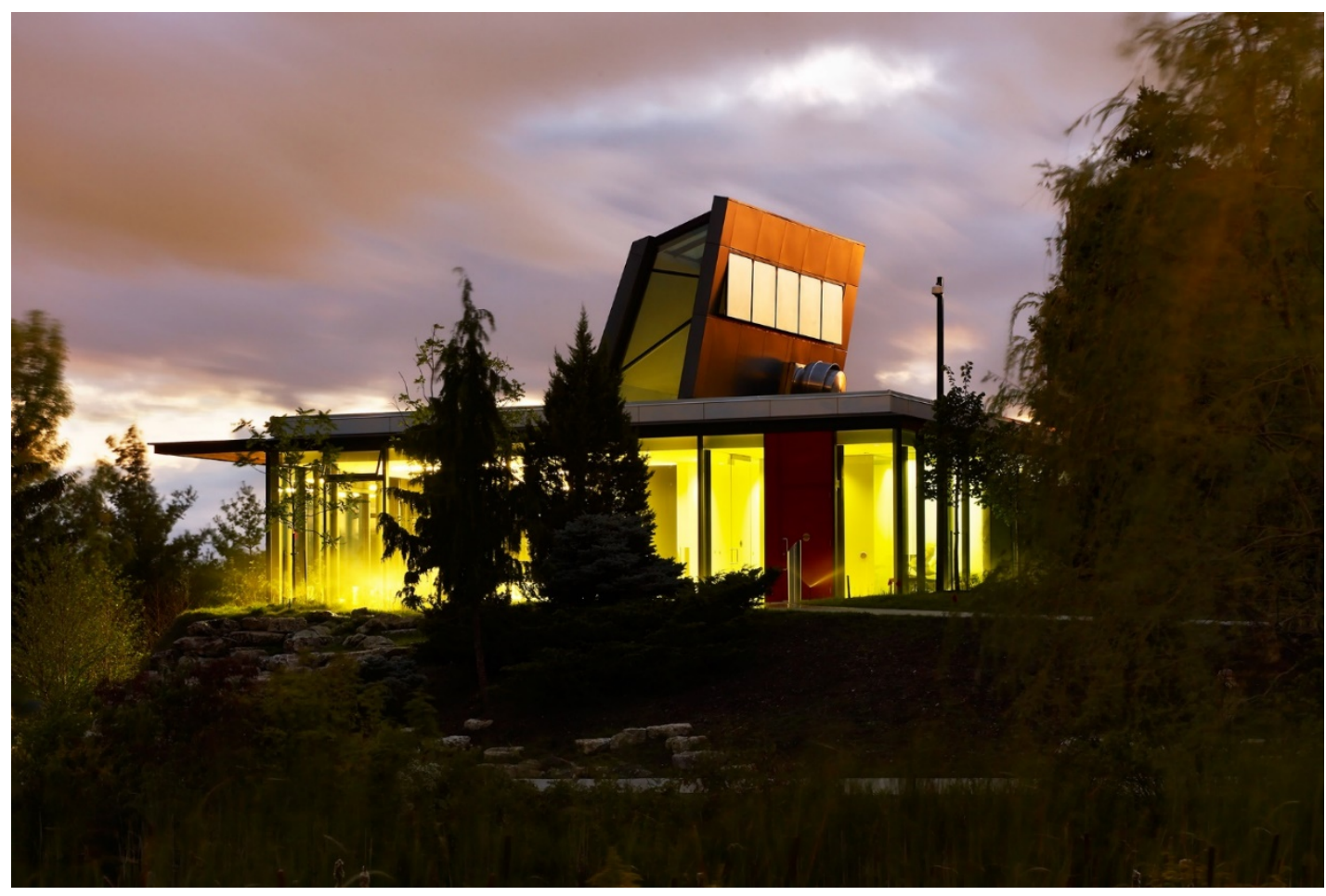

Figure 10. Humber Arboretum Centre for Urban Ecology Source: https://www.taylorhazell.com/portfolio/humberarboretum-centre/ (accessed on 3 June 2021).

Our assessment shows that the centre's educational mandate mainly focuses on experiential lessons rather than labeling and iconic lessons (Figure 11).

- $\quad$ Labeling $=$ Moderate

Humber's Centre for Urban Ecology will leave virtually no environmental impact from the standpoint of energy use and waste [68]. The centre demonstrates energy efficiency, environmentally friendly building materials, solar power, wind power, on-site waste management, a living roof and many other green building techniques. In keeping with the sustainability focus of the project, most of the materials can be reused or recycled [68].

- $\quad$ Iconic $=$ Moderate

The building's large windows and simple but elegant design highlight the natural world outside [68]. In addition, a green roof, which can be seen on the second level, and a slatted solar awning symbolically convey the green message.

- $\quad$ Experiential $=$ High

The architectural goal of the project was to create a modern building signaling a change in values concerning sustainable development and energy conservation. By using materials and forms that would communicate architectural and engineering ideas to a wide range of visitors, a living laboratory was created [67]. Through examples, the building teaches how we can all help reduce greenhouse gas emissions, clean up our rivers and work towards a healthy sustainable environment in our own urban spaces, said John A. Macintyre, chair, Humber Arboretum Management Committee [68]. It will be a tangible and enjoyable way for people to get engaged in improving their environment [68]. The building plan is organized according to the students' arrival and the sequence of the teaching program. It 
provides environmental education to primary, secondary, college and university students and promotes the advancement of ecological technology in service to preserve the natural world. There is an upper orientation classroom and a lower working project room that breaks out into the outdoor classroom [67]. On the lower level, educational displays and materials encourage kids to explore the habitats which can be found right outside the door [69].

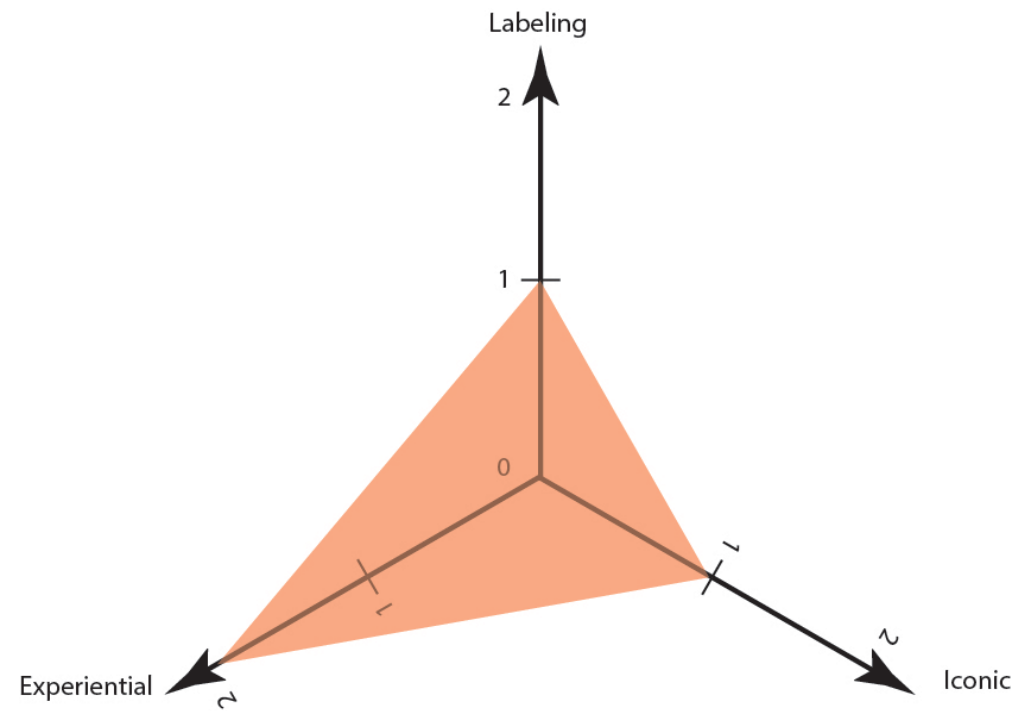

Figure 11. Importance levels of eco-lessons in Humber Arboretum Centre for Urban Ecology.

\subsection{Beamish Munro Hall Building}

Completed in September 2004, the Beamish Munro Hall building (also known as the Integrated Learning Centre) was designed by B $+\mathrm{H}$ Architects. This three-story building is located on Queen's University campus in Kingston, Ontario. Constructed between two existing buildings on the campus, it serves as a connection between these two buildings. The central atrium makes up the heart of the building, and six engineering faculties are organized around it (Figure 12) [70]. The building received the RAIC Awards of Excellence in innovation in architecture in 2005 by the Royal Architectural Institute of Canada (RAIC) [71]. Moreover, the building received "Four Green Leafs" out of five offered by BREEAM's Green Leaf Eco-Rating Program - a certification that indicates "national industry- leadership in terms of eco-efficiency design, practices and management commitment to continuous improvement and industry leadership" [72]. 


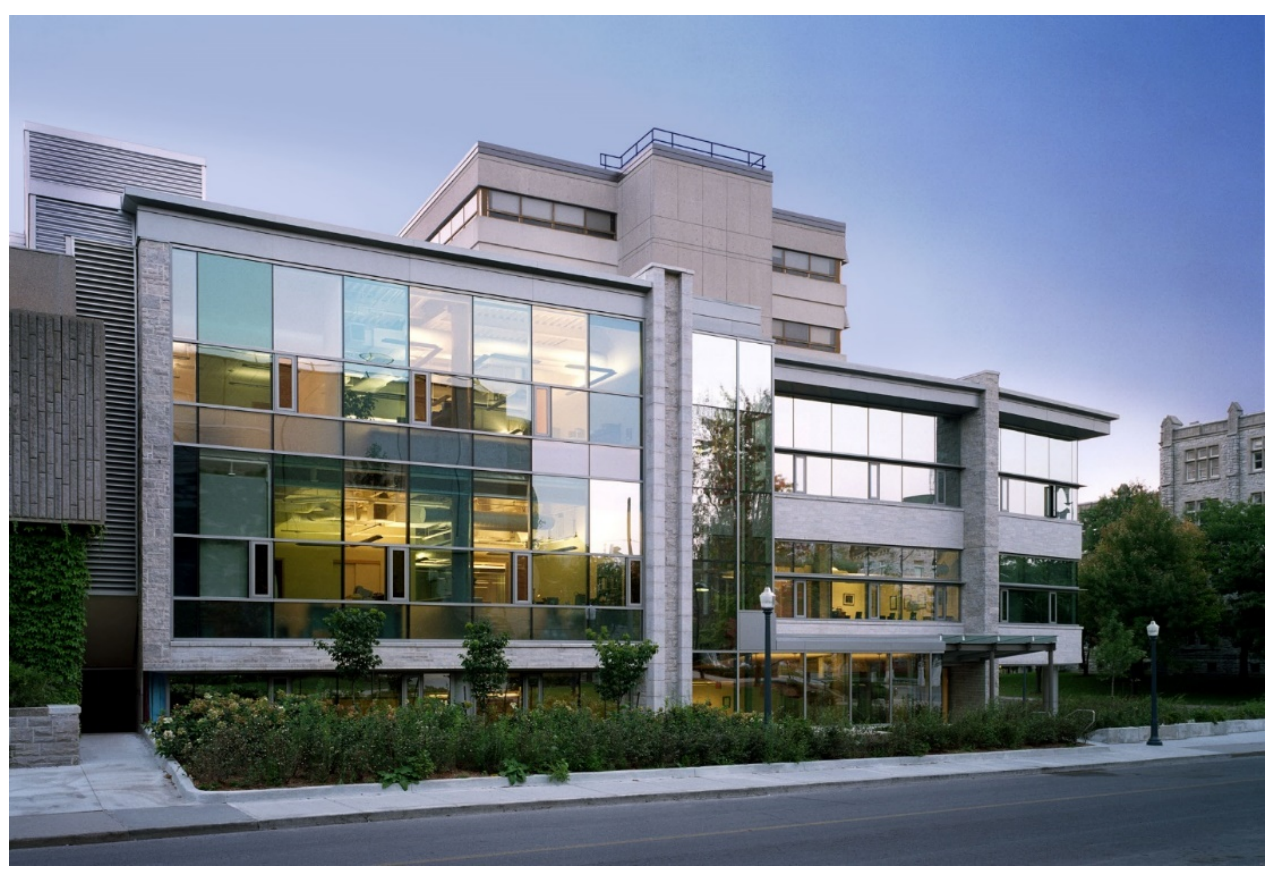

Figure 12. Integrated Learning Centre-Beamish Munro Hall. Source: https:/ /bharchitects.com/en/ project/beamish-munro-halls-integrated-learning-centre/ (accessed on 3 June 2021).

Our assessment shows that all three types of our introduced eco-lessons can be found in this building, and the building highly emphasizes all of them (Figure 13).

- $\quad$ Labeling $=$ High

The building's energy features include a focus on renewable solar energy use (through the photovoltaic panels), radiant flooring, temperature sensors, as well as other heating and ventilation technologies (such as the heat recovery wheel, the variable-speed fans, the convective air movement design and the steam-heating system) [72].

\section{- $\quad$ Iconic $=$ High}

Jen [73] names this building "green machine". This name is not only based on the building's various energy saving systems, but also on the green features exhibited by a large green wall in the central atrium.

\section{- $\quad$ Experiential $=$ High}

The pedagogical function of this building is a clear example of a structure that teaches sustainability. Here, building elements and systems are presented to students and act as active learning tools [72]. This is vividly exemplified by the visible system and structure cut-outs, as proposed by Torres [72]. For example, a wall in the student lounge is cut to reveal the various layers of material that compose it. One of the main learning instruments in the ILC is the green entrance wall, which also improves the air quality by removing up to $90 \%$ of air pollutants [72]. The building's pedagogical role is not limited to its structure and systems, but also extends to its performance. In fact, Torres names the building a "live building" since the students can monitor the building's performance through screens and metrics, which show how much carbon dioxide is produced and how much the building's green components mitigate such emissions. This valuable feature compliments regular classroom activity and improves building design. Jen [72] explains that the educational role of the building was one of the factors in the initial phase of building design. "Both the client and the architect agreed that the building should educate and increase awareness of environmental and sustainable issues, such that the students may take the valuable lessons learned with them to their careers in professional practice." Torres [72] mentioned that 
this teaching ability is focused not only on the students in their classroom, but also on the university's community and broader society, including staff, faculty, and visitors:

“The students' learning capacity and the building's innovative-technologies teaching characteristic create an integrated learning experience that enriches not only ILC'S students but the entire Queen's community in an environmentally responsible manner. [ ... I The building itself promotes sustainability and teaches engineering concepts to the entire community; not only are engineering students affected by its presence, but also staff, visitors, and the general public are becoming subject to interaction with the ILC's outstanding standards in education and building performance." [72]

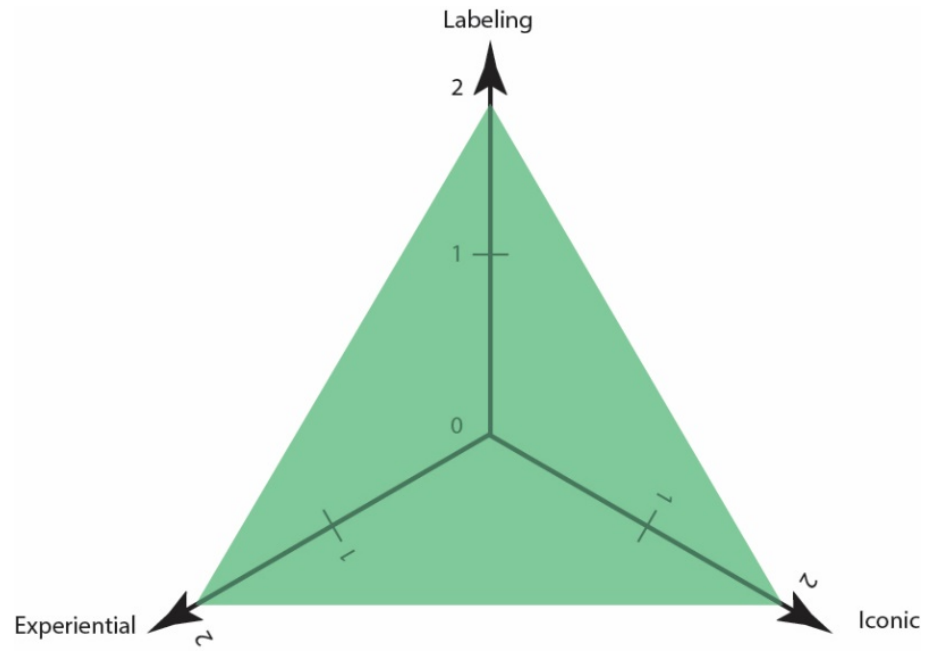

Figure 13. Importance levels of eco-lessons in Integrated Learning Centre-Beamish Munro Hall.

\subsection{University of Guelph-Humber}

Founded in 2002, the University of Guelph-Humber originates from a partnership between the University of Guelph and Humber College in Toronto, Ontario. This four-story building opened to the public in May 2004. It was designed by Diamond and Schmitt Architects in a joint venture with RHL Architects. The project has a size of 50,000 sq. ft. and incorporates a range of facilities such as classrooms, computer labs, studios, offices, and informal gathering spaces. In 2005, the building received the RAIC Awards of Excellence, in Innovation in architecture from the Royal Architectural Institute of Canada [73] (Figure 14).

Our assessment shows that the building highly focuses on all three eco-lessons: experiential, labeling and iconic lessons (Figure 15).

- $\quad$ Labeling $=$ High

A displacement ventilation system and a biofilter wall are two of the main sustainable approaches that have been applied to enhance the building's performance. The displacement ventilation causes natural convection that mitigates the energy consumption of fans and quickly exhausts stale air. This is done with the help of the atrium's design, which acts as a four-story chimney. In addition, the biofilter wall naturally cleans, cools and humidifies the indoor environment [74]. The living wall is intended to cool indoor air during the summer and work as a humidifier during winter by using the plants' natural respiratory properties. The architects describe the biofilter wall as such:

"This living wall biofilter measures $10 \mathrm{~m}$ wide and $16 \mathrm{~m}$ high for a total area of approximately $160 \mathrm{~m}^{2}$. This is our first living wall and still one of our largest. Fully integrated into the building air-handling systems, and capable of delivering 40,000 CPM, this living wall biofilter is supplied by natural light, and supplemented with architectural lighting. This living wall contributed towards the building receiving a 2005 award of excellence from the Royal Architecture Institute of Canada". [75] 


\section{- $\quad$ Iconic $=$ High}

The biofilter green wall, a visual focal point of the building's atrium, acts as a symbolic and eco-didactic tool. It teaches sustainability to the researchers, students and staff.

- $\quad$ Experiential $=$ High

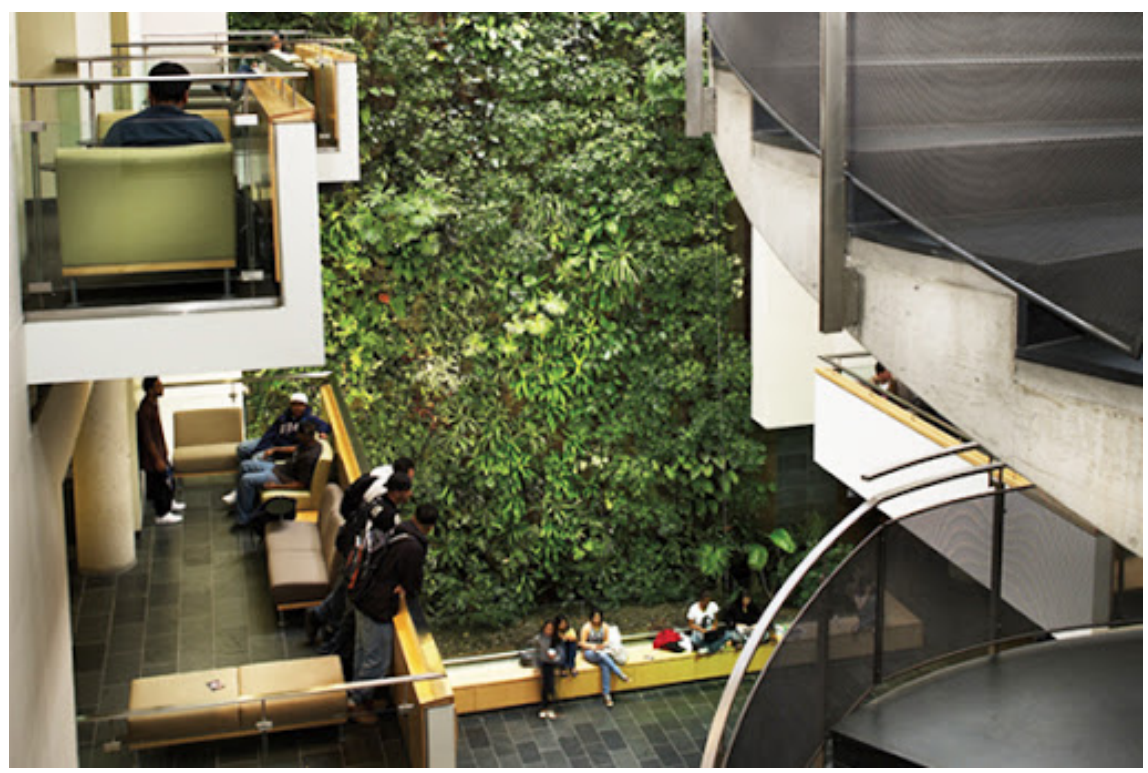

Figure 14. University of Guelph-Humber. Source: http:/ / nedlawlivingwalls.com/cubeportfolio/ university-of-guelph-humber/ (accessed on 3 June 2021).

The jury of the 2005 RAIC Awards of Excellence mentioned that this building advances our knowledge of these systems towards developing better designs by addressing the challenges of sustainability. The biofilter wall and the ventilation system are the two main sustainable "organs" of the building. They serve as technical tools to enhance the building's performance and perform as eco-didactic elements that teach sustainability to the researchers, students and staff. This mission is done on two levels. On the one hand, it targets researchers who monitor these respiratory systems of the building. For example, the green biofilter wall is monitored by a sophisticated building management system (BMS) that supports ongoing research into air quality monitoring, heating, cooling, humidification and energy consumption [74]. On the other hand, it focuses on educating the whole community of the university-students, professors, and staff-by visually conveying a green message through the bio filter wall. In this regard, the university also dedicates a page on its website to describe the biofilter wall [76]. This confirms that both the architects as well as the building's patrons tried to emphasize the didactic aspects of these sustainable organs. 


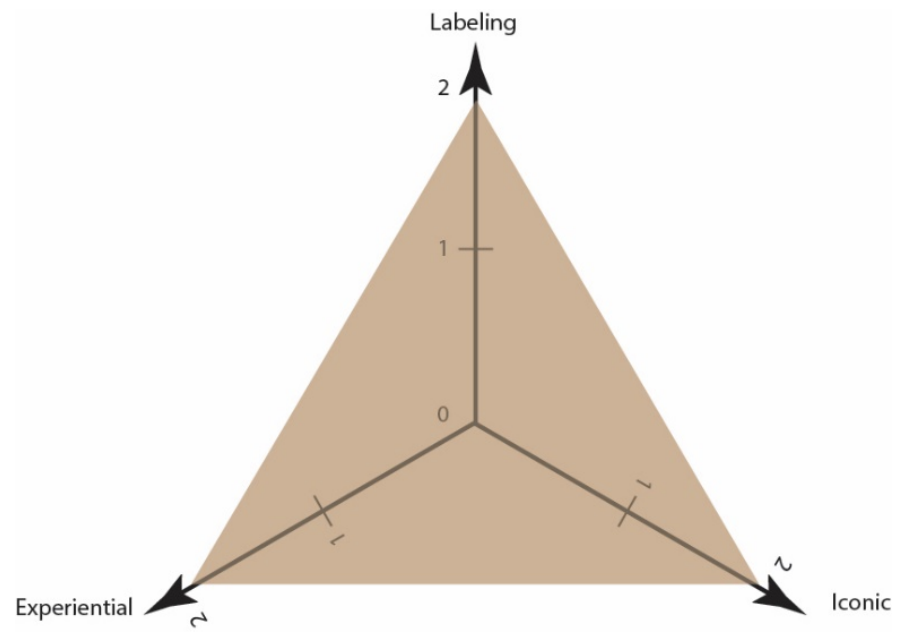

Figure 15. Importance levels of eco-lessons in University of Guelph-Humber.

\section{Conclusions}

We can now better define what we presented as three epistemological filters or Architectural Educational Strategies (AES) to categorize contemporary practices:

- The Labeling approach puts an emphasis on a series of environmental attributes, norms, labels or standards characteristic of green architecture. The label is often attached to the building not only discursively but physically as a proof of exemplarity, for example on the front entrance or in the naming of the building (e.g., Leed Gold Learning Centre).

- The Experiential approach is the more practical one as it presents all or part of a building as a learning tool to be understood through haptic of physical experiences (e.g., the lobby or main atrium defined as a learning space within the learning centre).

- The Iconic method is less quantitative than the labeling one and rarely offers an experience. It relies on a visual narrative which puts emphasis on visible and identifiable symbolic devices of ecological architecture (e.g., the green roof, green wall or solar roof as visible attributes of the learning centre).

Our comparisons reveal that the experiential approach is naturally favored by architects when designing a learning centre. While it remains impossible to generalize at this stage of the research, labeling and iconic strategies would tend to be more exclusive and less hybrid than the experiential approaches. We also underlined a gradient between superficial and deep "eco-lessons."

Having outlined behaviorism, cognitivism and constructivism as three important trends in education and instructional design, we can interrogate their potential influence on the three types of Architectural Educational Strategies. Preliminary analysis suggests that behaviorism has had minimal impact on either of the three identified categories of labeling, experiential and iconic strategies. Indeed, we found little evidence that reinforcement or operant conditioning plays any relevant part in architectural lesson-giving. However, our research indicates that cognitivist methods resonate rather well with the eco-didactic formula. While one should be careful not to draw parallels where there are none, we believe that cognitivism is compatible with the labeling and iconic approaches. Given the fact that cognitivists stress the acquisition of knowledge through conceptual and symbolic means, it appears that the labeling and iconic strategies, which transmit value-laden content, could be considered as subgenres of cognitivist pedagogy. By favoring standardized communication methods, labeling and iconic AES aim to facilitate the transfer of information from teacher to student. Such an aspiration is also entertained by cognitivists. Furthermore, we believe that constructivism is compatible with the experiential approach. Since constructivism and affiliated views emphasize the construction of knowledge through experience, it seems like the experiential strategies, which give priority to the learner, could be deemed as 
subgenres of constructivist pedagogy. By favoring interaction between the subject and his environment, the experiential approach aims to provide a more involving learning process. As we have seen, this concern is also shared by constructivists. In summary, it can be stated that labeling and iconic strategies are more akin to cognitivism, while the experiential ones have more in common with constructivism.

Having looked at three Architectural Education Strategies from the standpoint of their didactic potential, we believe that future research could better address the broader topic of social transformation through eco-didactic means. Eco-didacticism claims that an architectural object, like a school or a research centre, can be a lesson in itself. That is, by transforming a physical space, one can also transform the very subject who exists in that space. Many architects, designers and critics believe that forms of architectural communication can operate as elements of a formal language that would be accessible to non-experts. Does this fall within a traditional educational role of architecture or is it a new phenomenon? Architecture has always been a support and somehow a didactic display of power be it military, religious, autocratic or democratic and, like artistic practices, architecture carries symbolic meanings. However, architectural practices differ from artistic practices in their pragmatic mandate embodied by a brief or program. In the field of public commissions, architects do not have the leisure to behave as activists or "environmental consciousness raisers" if not through the intermediary of the qualities specific to the projects they design. In this sense, eco-didacticism purports that architecture can educate citizens about environmental issues and communicate ecological concepts.

Future research could also question the very possibility of giving lessons through formal language and aesthetic features. Dewey and Chomsky, to name only these two, were well aware of the connection between the learning space itself and the individuals living inside of it. In his theory of Laboratory Schools, Dewey stated that material conditions should be compatible with one's educational vision [77]. Furthermore, the architectural design of the school should be internally cohesive, while remaining connected to the external world. Echoing Dewey's thoughts, Chomsky would go so far to conclude that the "environment is the curriculum" [24]. Such a conviction is also held by Elliot Eisner, leading scholar of arts education, who believed that learning environments, properly designed, could stimulate creativity and imagination [78]. If such hypotheses are verified, then architecture can convey meaning and act on the public itself. In other words, architectural design has the power to exert change through aesthetic language. However, if this is true, how exactly can architecture convey eco-didactic lessons and concepts? How exactly does one encode meaning into form?

Although the very possibility of communicating through architectural form is a characteristic feature of postmodern ideologies and theories, the type of communicational phenomenon we have analyzed here appears to be of a slightly different nature. The devices used in the case of learning centres are oriented toward a specific "clientele" in which students are targeted as mediators at the hinge between expert discourse and generic public reception. Since students are not the primary clients who happen to be in touch with designers throughout the design process of learning centres, we need to consider that the actual clients, say the agents of these educational buildings, are specifically requesting additional features, such as augmented didactic devices so to speak. Furthermore, the fact that experiential learning emerges as a main educational strategy points to a more sophisticated type of communicational intention. Borrowing from the field of semiotics, Umberto Eco argues that architecture is capable of both denotation and connotation [79]. Through significative forms or sign vehicles, objects of design denote their own function and connote the intention which underpins that very function. In other words, architectural entities, like stadiums, communicate their basic purpose (e.g., hosting events) and the mindset through which they were wrought (e.g., celebrating the economic prosperity of a city or the greatness of a leader). Conveniently, this framework can also be applied to eco-didacticism. It is our opinion that learning centres designed with sustainability in mind can express their primary function and also elicit reflection about ecology through rhetorical devices 
and processes of codification. Now, these discursive formulas need not be overly cryptic or abstract. By emphasizing the sustainable features of learning spaces (e.g., low carbon building materials, renewable energy, thermal efficiency ... ), one is capable of accessing the symbolic domain and expressing specific values. However, for eco-didacticism to succeed in communicating embedded lessons, the public must also possess prior knowledge of symbolic conventions and basic decoding skills. Furthermore, eco-didactic design cannot ensure that the various members of society will necessarily interpret eco-didactic messages in the same way. Being a participant in the dialogical process, the individual should enjoy a certain hermeneutic leeway when it comes to appraising eco-lessons [80]. As stated previously, education is a dynamic and constructive process which rests on the reflective agency of the citizen. Eco-didacticism embraces the idea of learning as rational inquiry and debate. Alleged limits to communicability and semantic mediation in architecture should not, ultimately, defeat the eco-didactic project. As a platform to present innovative solutions to environmental challenges, eco-didacticism need only use semiotic devices and purposefully designed spaces to educate the general public and incite social change.

Communication and education should certainly not be confused when analyzing eco-didacticism in architecture. We have selected awarded buildings keeping in mind that the systems for recognizing environmental quality through awards are by definition mediations of excellence and as such they also participate in a communicative system. The discourse most often points to an educational dimension that is added to ecological performance. This is what we call an "Architectural Educational Strategy" (AES). However, we also need to acknowledge a possible bias regarding the role of recognition through awards of excellence. We selected awarded sustainable architecture but we did not compare these cases with non-awarded ones. It is possible that award recognition amplifies ecolessons. We can say that award-winning projects are transformed into didactic models of ecological architecture by the effects of communication from both award organizations and professional journals that often simply pass on the press releases.

As a possible interpretation of the rise of eco-didacticism in architecture and the built environment, we propose to consider a shift from experimental approaches to sustainability to partially pedagogical transformation of buildings. In the same way that ecological movements have shifted from a strictly activist form of environmentalism to more normative frameworks, we may have entered an era of educational environmentalism. Its mission is to render environmental qualities understandable beyond expert circles and, in such a societal shift, architecture would have a new didactic role to play in the built environment.

Author Contributions: J.-P.C.: overall direction of the research project, case studies, writing; M.H.: data collection, data analysis, writing; K.-A.P.: contribution to the literature review and complementary analysis of findings. All authors have read and agreed to the published version of the manuscript.

Funding: Social Sciences and Research Council of Canada \#435-2018-1161.

Institutional Review Board Statement: Not applicable.

Informed Consent Statement: Not applicable.

Data Availability Statement: Data available is contained within the article.

Conflicts of Interest: The authors declare no conflict of interest.

\section{References}

1. Cucuzzella, C.; Chupin, J.-P.; Hammond, C. Eco-didacticism in art and architecture: Design as means for raising awareness. Cities 2020, 102, 102728. [CrossRef]

2. The United Nations Sustainable Development Goals (SDGs). Available online: https:/ / sdg-tracker.org (accessed on 17 June 2021).

3. Michalos, A.C. Encyclopedia of Quality of Life and Well-Being Research; Springer: Dordrecht, The Netherlands, 2014 ; ISBN 9400707533.

4. Cucuzzella, C. Analyzing Eco-Architecture beyond Performance; Editions JFD: Montreal, QC, Canada, 2020; ISBN 2897990333.

5. Ricoeur, P. Le Conflit des Interprétations; Seuil: Paris, France, 1969. 
6. Ragin, C.C. The Comparative Method: Moving beyond Qualitative and Quantitative Strategies; Univ of California Press: Berkeley, CA, USA, 2014; ISBN 0520957350.

7. Rihoux, B.; Ragin, C.C. Configurational Comparative Methods: Qualitative Comparative Analysis (QCA) and Related Techniques; Sage Publications: Thousand Oaks, CA, USA, 2008; ISBN 1452210314.

8. Smelser, N.J. Comparative Methods in the Social Sciences; Quid Pro Books: New Orleans, Louisiana, 2013 ; ISBN 1610271777.

9. Frampton, K. A Genealogy of modern Architecture. Comparative Critical Analysis of Built Form; Lars Müller Publishers: Baden, Switzerland, 2015.

10. Haraguchi, H. A Comparative Analysis of 20th-Century Houses; John Wiley and Sons Ltd.: Hoboken, NJ, USA, 1988 ; ISBN 0856709425.

11. Singh, Y.J.; Lukman, A.; Flacke, J.; Zuidgeest, M.; Van Maarseveen, M. Measuring TOD around transit nodes-Towards TOD policy. Transp. Policy 2017, 56, 96-111. [CrossRef]

12. McCollum, D.; Gomez Echeverri, L.; Krey, V.; Rogelj, J.; Nilsson, M.; Busch, S.; Pachauri, S.; Stevance, A.-S.; Parkinson, S.; Minx, J.C.; et al. Connecting the sustainable development goals by their energy inter-linkages. Environ. Res. Lett. 2018. [CrossRef]

13. Allen, C.; Metternicht, G.; Wiedmann, T. Prioritising SDG targets: Assessing baselines, gaps and interlinkages. Sustain. Sci. 2019, 14, 421-438. [CrossRef]

14. Dewey, J. How We Think; DC Heath \& Company: London, UK, 1910.

15. Dewey, J. Democracy and Education: An Introduction to the Philosophy of Education; The Macmillan Company: New York, NY, USA, 1923; ISBN 1548554499.

16. Dewey, J. Experience and education. In Proceedings of the Educational Forum; Taylor \& Francis: Oxford, UK, 1986; Volume 50, pp. 241-252.

17. Russell, B. Education and the Good Life; Boni \& Liveright: New York, NY, USA, 1926.

18. Russell, B. On Education: Especially in Early Childhood; Ruskin House: London, UK, 1930.

19. Russell, B. Education and the Social Order; George Allen \& Unwin LTD: London, UK, 1932; ISBN 113522353X.

20. Chomsky, N. Language and Mind, 3rd ed.; Cambridge University Press: New York, NY, USA, 2006; ISBN 0521858194.

21. Chomsky, N. Reflections on Language; Pantheon Books: New York, NY, USA, 1975.

22. Chomsky, N. Democracy and education. Counterpoints 2012, 422, 55-70.

23. Rockler, M.J. Russell vs. Dewey on education. Curr. Issues Educ. 1993, 10, 13-23.

24. Corson, D.J. Chomsky on Education. Aust. J. Educ. 1980, 24, 164-185. [CrossRef]

25. Corson, D.J. Chomsky on Education. Aust. J. Educ. 1980, 24, 176. [CrossRef]

26. Thorndike, E.L. The Fundamentals of Learning; Teachers College Bureau of Publications: New York, NY, USA, 1932.

27. Thorndike, E.L. Educational Psychology; Teachers College, Columbia University: New York, NY, USA, 1913.

28. Watson, J.B. Psychology: From the Standpoint of a Behaviorist; JB Lippincott: Philadelphia, PA, USA, 1919.

29. Watson, J.B. Behavior: An Introduction to Comparative Psychology; Henry Holt and Company: New York, NY, USA, 1914; ISBN 0722220693.

30. Skinner, B.F. The science of learning and the art of teaching. Harv. Educ. Rev. 1954, 24, 86-97.

31. Skinner, B.F. Verbal Behavior; Appleton-Century-Crofts, Inc.: New York, NY, USA, 1957.

32. Cooper, P.A. Paradigm shifts in designed instruction: From behaviorism to cognitivism to constructivism. Educ. Technol. 1993, 33, $12-19$.

33. Ertmer, P.A.; Newby, T.J. Behaviorism, cognitivism, constructivism: Comparing critical features from an instructional design perspective. Perform. Improv. Q. 1993, 6, 50-72. [CrossRef]

34. Mandler, G. Origins of the cognitive(r) evolution. J. Hist. Behav. Sci. 2002, 38, 339-353. [CrossRef] [PubMed]

35. Chomsky, N. Syntactic Structures; The Hague Mouton: Berlin, Germany, 1957; ISBN 9027933855.

36. Chomsky, N. Verbal Behavior by BF Skinner: A review. Language 1959, 35, 26-58. [CrossRef]

37. Piaget, J. Science of Education and the Psychology of the Child; Orion: New York, NY, USA, 1970.

38. Piaget, J. The Language and Thought of the Child; Kegan Paul, Trench, Trubner \& Co. LTD: London, UK, $1926 ;$ ISBN 0415267501.

39. Bruner, J.S. The Process of Education; Harvard University Press: Cambridge, MA, USA, 1960; ISBN 0674028996.

40. Bruner, J.S. Going beyond the Information Given; W. W. Norton: New York, NY, USA, 1973.

41. Vygotsky, L.S. Thinking and speech. In The Collected Works of LS Vygotsky; Rieber, R.W., Carton, A., Eds.; Plenum Press: New York, NY, USA, 1987; Volume 1, pp. 39-285.

42. Vygotsky, L.S. Mind in Society: The Development of Higher Psychological Processes; Harvard University Press: Cambridge, MA, USA, 1980; ISBN 0674076680.

43. Rogers, C.R.; Freiberg, H.J. Freedom to Learn; Charles Merrill: Columbus, OH, USA, 1970.

44. Mohawk College Joyce Centre for Partnership \& Innovation. Available online: https://bharchitects.com/en/project/mohawkcollege-joyce-centre-for-partnership-innovation/ (accessed on 2 June 2021).

45. Atlas of Research on Exemplarity in Architecture and the Built Environment. Available online: https://architecture-excellence. $\mathrm{org} /$ test $/$ ?s=\%22THE+JOYCE+CENTRE+FOR+PARTNERSHIP+\%22 (accessed on 19 June 2021).

46. Mohawk Receives Canada's First Zero Carbon Dual Certification. Available online: https://www.mohawknewsdesk.ca/ mohawk-received-canadas-first-zero-carbon-dual-certification/ (accessed on 3 June 2021).

47. $\mathrm{B}+\mathrm{H}$ and mcCallumSather's Joyce Centre certified a 'Zero Carbon Building. Available online: https:/ / www.canadianarchitect. com/bh-mccallumsathers-joyce-centre-certified-zero-carbon-building/ (accessed on 3 June 2021). 
48. The Joyce Centre for Partnership \& Innovation. Available online: https:/ /www.mccallumsather.com/projects/joyce-centrepartnership-innovation/ (accessed on 5 June 2021).

49. The Joyce Centre for Partnership \& Innovation at Mohawk College Canada's Second Zero Carbon Building-Design Certification. Available online: https:/ / www.cagbc.org/CAGBC/Zero_Carbon/Project_Profiles/Mohawk_Profile.aspx (accessed on 13 June 2021).

50. Kandel, M. New Mohawk Lab Will be Canada's Largest “Net Zero” Energy Use Building. Available online: https://www.cbc.ca/ news/canada/hamilton/largest-net-zero-building-in-canada-1.4567437 (accessed on 13 June 2021).

51. Atlas of Research on Exemplarity in Architecture and Built Environment. Available online: https://architecture-excellence.org/ test $/$ ?s=\%22wood+innovation $\% 22$ (accessed on 10 June 2021).

52. Hooper, E. Innovative Detail: Wood Innovation and Design Centre. Available online: https://www.architectmagazine.com/ technology / detail/innovative-detail-wood-innovation-and-design-centre_o (accessed on 10 June 2021).

53. Wood Innovation and Design Centre. Available online: https://wood-works.ca/wp-content/uploads/151203-WoodWorksWIDC-Case-Study-WEB.pdf (accessed on 1 June 2021).

54. Governor General's Medal Winner: Wood Innovation and Design Centre. Available online: https://www.canadianarchitect.com/ governor-generals-wood/ (accessed on 9 June 2021).

55. Penner, D. Prince George Centre Opens as Towering Presence in All-Wood Construction Sector. Available online: https://vancouversun.com/Business/commercial\%20real\%20estate/prince-george-centre-opens-as-towering-presencein-all-wood-construction-sector?r (accessed on 1 June 2021).

56. RAIC Awards-Innovation in Architecture: Wood Innovation Design Centre, Prince George, British Columbia. Available online: https: / / www.canadianarchitect.com/raic-awards-innovation-in-architecture-2/ (accessed on 8 June 2021).

57. Boddy, T. Apostle of Wood: Wood Innovation and Design Centre and Ronald McDonald House BC \& Yukon, British Columbia. Available online: https: / www.canadianarchitect.com/1003730141/ (accessed on 7 June 2021).

58. DIALOG Science on Display. Available online: https://archello.com/project/energy-environment-experiential-learninguniversity-of-calgary-calgary-ab (accessed on 13 June 2021).

59. Atlas of Research on Exemplarity in Architecture and the Built Environment. Available online: https://architecture-excellence. org/?s=ENERGY.+ENVIRONMENT.+EXPERIENTIAL+LEARNING (accessed on 19 June 2021).

60. McIntosh, A. Energy. Environment. Experiential Learning, University of Calgary, Alberta. Can. Arch. 2013, 58, 16.

61. Energy Environment Experiential Learning Built History. Available online: https://asc.ucalgary.ca/building/energyenvironment-experiential-learning/ (accessed on 13 June 2021).

62. Perkins \& Will Centre for Interactive Research on Sustainability /Perkins + Will. Available online: https://www.archdaily.com/ 343442/centre-for-interactive-research-on-sustainability-perkins-will (accessed on 13 June 2021).

63. The CIRS Building. Available online: https:/ / cirs.ubc.ca/building/building-overview/ (accessed on 13 June 2021).

64. Atlas of Research on Exemplarity in Architecture and the Built Environment. Available online: https://architecture-excellence. $\mathrm{org} /$ ?s=Centre+for+Interactive+Research+on+Sustainability+ (accessed on 19 June 2021).

65. Humber Arboretum and Centre for Urban Ecology Policy. Available online: https://humber.ca/legal-and-risk-management/ policies/general-administration/humber-arboretum-and-centre-for-urban-ecology-policy.html (accessed on 14 June 2021).

66. Humber Arboretum Centre for Urban Ecology. Available online: https://www.taylorhazell.com/portfolio/humber-arboretumcentre/ (accessed on 9 June 2021).

67. Leslie, J. Everything's Gone Green. Available online: https://www.canadianarchitect.com/everything-s-gone-green/ (accessed on 9 June 2021).

68. Humber Arboretum's Centre for Urban Ecology. Available online: https://www.toronto.ca/311/knowledgebase/kb/docs/ articles/private/humber-arboretums-centre-for-urban-ecology.html (accessed on 14 June 2021).

69. Humber, A. The Centre for Urban Ecology. Available online: https:/ /humber.ca/arboretum/explore/centre-for-urban-ecology. html (accessed on 31 May 2021).

70. Engineered for Success Queens University Beamish-Munro Hall's Integrated Learning Centre. Available online: https:// bharchitects.com/en/project/beamish-munro-halls-integrated-learning-centre/ (accessed on 13 June 2021).

71. Atlas of Research on Exemplarity in Architecture and the Built Environment. Available online: https://architecture-excellence. org/?s=Beamish+Munro+Hall+ (accessed on 19 June 2021).

72. Jen, L. Green Machine. Can. Archit. 2005, 50, 16-18.

73. Atlas of Research on Exemplarity in Architecture and the Built Environment. Available online: https://architecture-excellence. org /?s=Guelph+Humber (accessed on 19 June 2021).

74. Shotton, B. 2005 RAIC Awards of Excellence Innovation in Architecture. Available online: https:/ /www.canadianarchitect.com/ 2005-raic-awards-of-excellence/ (accessed on 12 June 2021).

75. Schmitt, D. University of Guelph-Humber. Available online: http://nedlawlivingwalls.com/cubeportfolio/university-of-guelphhumber/ (accessed on 11 June 2020).

76. The Plant Wall. Available online: https://www.guelphhumber.ca/about/plant-wall (accessed on 11 June 2020).

77. Wirth, A.G.; Bewig, C. John Dewey on school architecture. J. Aesthetic Educ. 1968, 2, 79-86. [CrossRef]

78. Eisner, E.W. What Really Counts in Schools. Educ. Lead. 1991, 48, 10-11. 
79. Eco, U. Function and Sign: The Semiotics of Architecture. In Rethinking Architecture: A Reader in Cultural Theory; Leach, N., Ed.; Routledge: New York, NY, USA, 2005; pp. 173-195, ISBN 0415128269.

80. Smith, R.W.; Bugni, V. Symbolic interaction theory and architecture. Symb. Interact. 2006, 29, 123-155. [CrossRef] 